Jędrzej M. Kondek

Uniwersytet Warszawski

e-mail: j.kondek@wpia.uw.edu.pl

\title{
Abrogation of Legal Effects of Usurpations in the Late Roman Empire
}

\begin{abstract}
SUMMARY
Abrogation of Legal Effects of Usurpations in the Late Roman Empire

Usurpations were not unusual situations in Ancient Rome. However, the term "tyrranus" was understood differently from its modern meaning. This word technically means "someone who came to power unlawfully", but in fact a person defeated by a new ruler was called an usurper, regardless of a way he had come to power. In such a way, e.g. Licinius was declared "tyrranus" although he had come to power as a legal augustus.

Constitutions against usurpers in the Theodosian Code do not constitute a homogenous group. We could divide them into acts regarding an usurper's legislation, acts regarding civil law actions (e.g. slave emancipations), acts regarding public law actions (e.g. nominations of magistrates) and acts regarding the emperor's sentences. It is meaningful that there is no usurper against whom all the above-mentioned types of constitutions were promulgated.

Civil law acts and sentences were generally upheld. In most cases, legislation was abolished only to the extent in which it was contra ius. Only Constantinus against Licinius (CTh. XV, 14, 1) and Honorius and Theodosius II against Heraclianus (CTh. XV, 14, 13) decided to abrogate the entire the legal output of the usurpation. Valenitianus II, Theodosius II and Honorius were the only emperors (except CTh XV, 14, 13) who abrogated all sentences of the usurpers. In almost all cases, nominations made by the usurper were annulled.

However, while all usurpations (except Licinius's usurpation) had taken place only in its Western Part, it should be noticed that all the analyzed constitutions were promulgated by all simultaneous rulers of the Empire even after 395 AD.

The question is why Theodosian compilers decided to include the analyzed constitutions into the Code. In my opinion, the most probable answer is that the Chapter De infirmandis... should have served for the legitimation of the rules of the current Emperor, as until the end of the Empire there were no rules of succession of power. In all analyzed constitutions, the legal
\end{abstract}

* Faculty of Law and Administration, University of Warsaw. 
emperor referred to an output of the illegal ruler. Theodosius, evoking those constitutions and demonstrating his continuity with their authors, presented himself as the legal ruler and put all his opponents in the position of usurpers.

Key words: usurper, Roman constitutional law, Constitutions, abrogation

\section{Introduction}

\subsection{Introductory remarks}

Usurpations $^{1}$ of power in the Roman Empire were quite frequent. R. Suski ${ }^{2}$ lists 76 usurpers between $86-468 \mathrm{AD}, 24$ of which existed beginning from the time of Constantine the Great. The line between usurpation and legitimate reign was indeed smooth. Usurpers often obtained an acknowledgment of their power, only to lose it later. Legitimate emperor Licinius was found to be a tyrant after his defeat in the war with Constantine, who came to power not quite legally, breaking the rules established in Diocletian's Tetrarchy. So finally the usurper became the ruler, replacing the ruler who lost the conflict. The proclamation of a ruler as a tyrant, regardless of its moral connotations, meant that the ruler won his power contrary to existing law3.

All those usurpations exert their influence not only on political and social life, but also on the legal system. Rome - at that time - was a state of statutory and written $l^{4} w^{4}$, and therefore abrogation of the legal effects of the past order should be done (at least in principle) by an act of positive law and not by e.g. desuetudo ${ }^{5}$. We should notice that ordering legal relations after the usurpation

1 For remarks regarding an etymology of this word, cf. M. V. Escribano, Usurpación y religión en el s. IV d. de C. Paganismo, cristianismo y legitimación política, "Antigüedad y cristianismo: Monografías históricas sobre la Antigüedad tardía” 1990, no. 7, p. 250.

2 E. Wipszycka, R. Suski, Listy władców, [w:] Vademecum historyka starożytnej Grecji i Rzymu. Źródłoznawstwo starożytności klasycznej, red. E. Wipszycka t. 1/2, Warszawa 2001, p. 568-572.

3 M. V. Escribano, La ilegitimidad política en los textos historiográficos y jurídicos tardíos (Historia Augusta, Orosius, Codex Theodosianus), "Revue Internationale des Droits de l'Antiquités" 1997, $3^{e}$ Série, Tome XLIV, p. 103-104 oraz idem, Constantino y la rescissio actorum del tirano-usurpador, "Gerión" 1998, no. 16, p. 307-338.

4 On the problems of losing the binding force of legal acts in Roman law, see M. Zabłocka, $U$ źródet wspótczesnego prawodawstwa, [w:] Z dziejów kultury prawnej. Studia ofiarowane Profesorowi Juliuszowi Bardachowi w dziewięćdziesięciolecie urodzin, Warszawa 2004, p. 76-78.

5 Although it should be noted that the Roman lawyers were not alien to the practice of recognizing that an act loses its binding force because of many years of non-compliance. Such effect - according to I 4,3,12 was achieved with the second section of the Lex Acquilia (see also R. Zimmermann, The Law of Obligations. Roman foundations of the Civilian Tradition, Oxford 1996, p. 953-961). In case of abrogation of the effects of usurpations, however, quick and clear actions were needed. 
meant not only a reference to the legal acts issued in the time of usurpation, but also to judicial acts, administrative decisions, etc. The Theodosian Code contains thirteen constitutions relating to six usurpations, which took place in one hundred years (313-413). That period covers the reigns of Maxentius, Licinius, Magnentius, Magnus Maximus, Eugene and Heraclian.

These constitutions usually do not devote much space neither to the usurpation nor the usurper's activities to which they relate. They often did not mention even the name of the overthrown usurper which was replaced with the term tyrannus. Therefore, it is often difficult to reconstruct these legal actions, against which the constitution was issued. This applies especially to their legislative activity, and to court judgments because of their nature and number. Better known to us are the activities of usurpers in the field of granting offices and dignities or using repressions, since these were reflected in the sources.

It is not possible to analyze the activity of usurpers and the reaction to them made by the legitimate rulers without outlining at least the general circumstances of the rise to power and loss of it by the usurpers, their political purposes, religious beliefs or social origin. And this is due to the fact that usually these circumstances resulted in different treatment given to their legal acts and in the scope of remedial actions taken by the legal emperors. They are also an interpretive indication that allows making at least an attempt to reconstruct the legal actions of the usurpers. For this reason, the analysis of the particular constitutions will be preceded by a brief sketch of the most important events and circumstances surrounding the usurpation and its overthrow, without which the picture emerging from the content of abrogation constitutions would be incomplete.

\subsection{Sources and literature}

Written sources for the late Roman Empire, except those of the imperial constitutions, are especially the works of Christian writers. Because of the role played by Christianity in the future centuries, these works have survived almost intact to this day. Non-Christian texts of many writers of this period were out of luck.

The two most important sources for this period are: Historiae Ecclesiastica by Socrates Scholasticus and by Hermias Sozomen. Although they focused on the Church, it was impossible to detach this subject from its political and social context, especially because of the role of emperors in the spread of Christianity and the resolution of doctrinal disputes. Both secular writers are not interested in the details of theological disputes, and therefore they often simply declare (another thing, if true) that they do not understand them. They focus more on the history of the Church as an institution than as a doctrine of faith, and therefore they focus on the history of the decline of the Empire in general. 
The third work covering the period of our interest is the Church History by Theodoret Bishop of Cyrrhus (386 or 393-466). He used slightly different sources than Socrates and Sozomen, and his text also has some shortcomings from the historical and chronological point of view.

A chronicle of St. Jerome (347-420) also provides a lot of data, but that work is only a chronological set of events, moreover, it is quite briefly presented.

With the exception of St. Jerome, all the previously mentioned authors were Christians writing in Greek. The last great pagan historian, writing in Latin (though Greek in origin) was Ammianus Marcellinus (ca. 330 - ca. 395), author of Rerum Gestarum Libri XXXI, that was a continuation of Tacitus, covering the period 96-378 AD. To our times only one book survived covering the years 353-378 AD. That period is not directly associated with any of the usurpations, but may serve as an approximation of events of the era and their backgrounds.

An important source for this period is the work of Zosimos, the pagan Greek writer from the fifth century, which covers the period from the reign of Octavian Augustus up to the capture of Rome by the Goths in $410 \mathrm{AD}$. According to Zosimos all disasters of Rome had their origin in the renunciation of the old cults. Thus he was critical of the Christian emperors, and his History presents a different point of view from the works of Socrates and Sozomen, although similar in their scope.

The Theodosian Code was never a subject of comprehensive study in Polish ${ }^{6}$. Nevertheless, noteworthy is a work of K. Ilski and W. K. Maciejewski on the editing techniques of the Code $\mathrm{C}^{7}$. Basic information about the Code can be found in textbooks on Roman law, which, however, do not devote much space to the history of the sources of law. It is worth mentioning of books by W. Wołodkiewicz and M. Zablocka, K. Kolańczyk and W. Rozwadowski ${ }^{8}$.

Among the foreign literature there are notable works of J. Harries ${ }^{9}$, T. Honoré ${ }^{10}$ and the valuable work of M. V. Escribano ${ }^{11}$, who had taken the issues of usurpations and constitutions regarding them contained in the Theodosian Code.

6 Foreign literature was discussed by M. Stachura, Kodeks Teodozjusza - nowo odkrywane źródło historyczne, „Przegląd Historyczny” 2006, nr 3.

7 K. Ilski, W. Maciejewski, Technika redagowania Kodeksu Teodozjusza na tle ustawodawstwa antynestoriańskiego, „Czasopismo Prawno-Historyczne” 1996, nr 48, z. 1-2, s. 31-45.

8 W. Wołodkiewicz, M. Zabłocka, Prawo rzymskie. Instytucje, Warszawa 2009; K. Kolańczyk, Prawo rzymskie, Warszawa 1997; W. Rozwadowski, Prawo rzymskie. Zarys wykładu wraz z wyborem źródeł. Poznań 1991.

9 J. Harries, Law and Empire in Late Antiqiuty, Cambridge 1999. It should be noted that he does not deal with any of the constitution discussed in that article.

10 T. Honoré, Law in the crisis of Empire 379-455 AD: the Theodosian dynasty and its quaestors: with the Palingenesia of laws of the dynasty, Oxford 1998. However, the author focuses on palingenesia and analysis of the authorship of the individual constitutions, and he does not pay attention to the specific issues of our interest.

11 M. V. Escribano, La ilegitimidad..., p. 85-120. 
Remarkable are also general works, especially the Oxford ClassicalDictionary ${ }^{12}$ (referred to as OCD) and the American Encyclopaedia of the Roman Empire ${ }^{13}$ (the ERE). Among many websites devoted to the decline of the Roman Empire, noteworthy is only the American De imperatoribus romanis website ${ }^{14}$, which consists of biographies of Roman and Byzantine emperors and usurpers written by professors of American universities.

The issue of usurpation in general and legislative and jurisdictional output of particular usurpations, have not yet been touched upon more widely. Only M. V. Escribano and B. Sitek ${ }^{15}$ have dealt closer with constitutions contained in book XV, Title 14 of the Theodosian Code.

\subsection{Legal Terminology of the post-classical era ${ }^{16}$}

Modern history of Roman law calls the period corresponding to the decline of the Empire the post-classical era. Its characteristics are, on the one hand, the centralization of power and the law (which is reflected, among others areas, in the development of cognitio extra ordinem), development of the imperial bureaucracy (and therefore the public law legislation) and the general collapse of the legal culture. That regression, which took place mostly in the West, resulted from the economic crisis, barbarization of the administration and, in a sense, the origin of the emperors themselves, who coming from the provinces and making their careers in the army, did not understand the spirit and finesse of the law of the classical age.

Beginning from the pricipate, the primary source of Roman law was the imperial constitutions ${ }^{17}$. At the turn of the second and third century they became the sole source of law. They did not form a homogeneous category. Using these constitutions, it should be remembered that it included four types of acts, not necessarily of a normative, general and abstract nature ${ }^{18}$ (as an act is now defined). The main type (initially the only one) were edicts (edicta), modeled on the edicts of republican officials (praetors). Mandates (mandata) - were the instructions for the imperial officials, which, however, were binding upon their subordinates. Decrees (decreta) and rescripts (rescripta) were in their assumption

12 Oxford Classical Dictionary, Oxford 1999.

13 Encyclopaedia of the Roman Empire, New York 1992.

$14 \mathrm{http} / / / \mathrm{www}$. roman-emperors.org.

15 B. Sitek, Infamia w ustawodawstwie cesarzy rzymskich, Olsztyn 2003.

16 Regarding the law of the post-classical era in general, see J. Harries, Law and Empire in Late Antiqiuty, Cambridge 1999, whereas the legal terminology is the exclusive subject of work of M.I.D. Agudo, Estudio léxico de ,iura y leges”en el derecho roman vulgar occidental, Madrid 2003.

17 Cfr. W. Litewski, Historia źródeł prawa rzymskiego, Kraków 1989, p. 131-134.

18 See the Aulus Gellius definition discussed by J. Zabłocki, Kompetencje 'patres familias' i zgromadzeń ludowych w sprawach rodziny w świetle 'Noctes Atticae' Aulusa Gelliusa, p. 41 and next. 
the individual and specific acts. They owed their general legal force to the power of emperor's authority. Decrees were judgments issued by the emperor, rescripts were the official response of the emperor to legal questions that were sent to him.

With time, however, differences between these types of constitutions have blurred and the Theodosian Code does not distinguish them.

During the post-classical period a clear distinction between ius and lex took place ${ }^{19}$. Until that point, the former had meant either the law in general, or law in the subjective sense. Lex had meant a bill passed by the Assembly. With time, however, the term "ius" was extended to all sources of law, except those derived from the imperial constitutions. At the time ius, called also ius vetus or ius aniquum, covered former leges, plebiscita and senatus consulta as well as legal responses of lawyers with ius respondendi ex auctoritate principis.

The term lex (law) came to signify constitutions of the emperor, but once that word had meant only a law passed by the Assembly. It was because Romans felt that since the emperor received the power by law, his constitutions have the force of law ${ }^{20}$. Situating ius vetus as the contrary to lex was strongly grounded in legal consciousness and is also found in the constitutions analyzed below ${ }^{21}$.

\section{The Theodosian Code \\ 2.1. Origins of the Code}

Centralization and bureaucratization of the state administration progressing from the third century led to the intensification of imperial legislation with varying degrees of generality and abstraction. Administration of such a vast state (which was Rome) at that time faced considerable difficulties. One of the main problems were difficulties in communication between the capital (or imperial residence) and local officials. Those difficulties meant that the imperial constitutions have been largely known only in Rome, Constantinople and in the vicinity of the imperial residences. They were delivered to the provinces with delay, and sometimes not at all. Lack of any systematization in the scope of the constitutions resulted in legal disorder, which becomes evident at the end of the third century.

The answer to those problems was originally private collections of the imperial constitutions arranged by the officials for their own needs. They were not always

19 See W. Wołodkiewicz, Ius et lex w rzymskiej tradycji prawnej, „Ius et Lex” 2002, nr 1, p. 51-61.

20 Gaius. 1,5: ...Nec umquam dubitatum est, quin id legis vicem optineat, cum ipse imperator per legem imperium accipiat.

21 Cfr. S. Corcoran, The Empire of the tertarchs. Imperial pronouncements and government AD 284-324, Oxford 2000, p. 69-70. 
complete, because they were based only on the collections and libraries held by their authors. The first collection was the Codex Gregorianus covering the period from the reign of Hadrian to the year 293 AD. Its supplement was the Codex arranged probably by Hermogenianus an official of the imperial chancellery at $295 \mathrm{AD}$. The fact that after only two years there merged the need to supplement the first Code shows an enormous number of legislative acts of the emperor at that time.

Those collections solved the problem only partially. They were not continued, and besides, did not have an official character. Still in circulation there were constitutions in wording different from those recorded in the Gregorianus and Hermogenianus Code, or those that were not taken into account by the two authors.

An initiative of Emperor Theodosius II, aiming to organize and revise existing legislation, was the breakthrough. It resulted in the publication in $438 \mathrm{AD}$ of a collection of legislative acts known as the Codex Theodosianus having effect from 1 January $439 \mathrm{AD}^{22}$. Initially it was just an act of Theodosius II and was in force only in the East, but soon it was adopted by Valentinian III in the West ${ }^{23}$. Constitutions issued in the years 438-468 - Novellae Posttheodosiane - are traditionally attached to every edition of the Code.

\subsection{Characteristics of the Code and its role in Roman law}

Unlike the previous collections, the Theodosian Code was an official collection. It meant that existing imperial constitutions retained binding force only if they were included to the Code and only in the wording determined by the Code. It covered the constitutions since the year $312 \mathrm{AD}$. The Gregorian or Hermogenian Codes were still in use for constitutions issued before 295 AD, whereas constitutions issued between 295 and 312 AD were deprived of such a collection (or perhaps it has not survived to our times).

The Code arranged the legislation of the Empire. As a consequence of that, all imperial constitutions issued during 126 years were collected in one Code. Also, their content was unified. It is not inconceivable that Theodosian codifiers, following the rule that the constitutions shall remain in force only in the version established in the Code, made corrections and changes in their wording. Such

22 About the circumstances of the creation of the Code, and the codification techniques, see K. Ilski, W. Maciejewski, op. cit., p. 31-44. Comments included in this work - although related directly to other issues - are also a valuable indication to matters under our considerations. They indicate that the constitutions contained in the Code were subjected to significant changes (which we now call interpolations) in comparison with their original versions.

23 Analysis of the preserved minutes of Roman Senate from the promulgation of the Code in the West is presented by W. Wołodkiewicz, Promulgacja Kodeksu Teodozjusza na posiedzeniu senatu miasta Rzymu, „Palestra” 2006, nr 1-2, p. 120-124. 
an assumption is plausible taking into account codification techniques used a century later by Tribonian during the preparation of the Code of Justinian (Emblema-ta Tryboniana) ${ }^{24}$.

The Code also played an important role in the later development of Roman law. By the year $534 \mathrm{AD}$ - so until the entry into force of the Justinian Codification - it was the most comprehensive source of Roman law. Since the range of the Justinian Code was limited only to the East, the impact of the Code of Theodosius on the West was even greater. On the Theodosian Code - alongside the works of Roman jurists - were based the first barbaric codifications: Breviary of Alaric of 506 as well as the Edict of Theodoric and Lex Romana Burgundiorum, both from the turn of the V and VI centuries. Those in turn constituted the basis of law in Western Europe until the time of rediscovery Justinian Codification and the works of glossators in the eleventh century.

\subsection{Systematics of the Code and the place of title 14 of book XV}

Constitutions contained in the Code were collected in 16 books, each divided into titles. Each title applies to one problem, and contains constitutions covering it. Under one title the constitutions are put chronologically from the earliest to the latest. Codifiers supplied each constitution with a preface, informing the reader who issued it, and to whom it was addressed, and with a footnote, which informs about a place and date of an issue.

The provisions concerning the usurpation were included in the book $\mathrm{XV}$, title 14: De infirmandis his, quae sub tyrannis aut barbaris gesta sunt - "About the cancellation of what was issued during times of tyrants and barbarians". It consists of fourteen constitutions: four of Constantine the Great, one of Constantius II, three of Valentinian, Theodosius and Arcadius, four of Honorius and Arcadius and two of Honorius and Theodosius II. Thirteen of them concern the usurpations, and the last one relates to the invasion of barbarians. According to the official dating, they embrace the period between 324 and $416 \mathrm{AD}$, but the dating of the first constitutions is doubtful (see below).

24 Interventions in the texts of constitutions during preparation of the Theodosian Code were explicitly allowed - albeit to a limited extent - by the instructions for the codification commissions (C.Th. I,1,5 and CTh., I,1,6). See also M. Stachura, op. cit., p. 313-314. 


\section{The constitutions of Constantine the Great (CTh. XV, 14,1 - XV, 14,4) \\ 3.1. The political situation in the Empire from Diocletian's abdication to defeat of Licinius}

When on May 1, 305 AD Diocletian and Maximinus abdicated, new augustuses, according to the rules of tetrarchy, became hitherto caesars Constantius Chlorus in the West and Galerius in the East. The new caesars became Maximin Daja and Severus. However, a decomposition of the system created by Diocletian occurred soon. The tetrarchy broke down just after one year, when in $306 \mathrm{AD}$ Constantius died, and the army elected as augustus his son Constantine. In $307 \mathrm{AD}$ the Empire was ruled at the same time by six rulers, whereas Diocletian's system allowed for two augustuses and two caesars ruling simultaneously. Five of them used the title of augustus, and the relationships between them were not ideal. After the Constantine's victory at Mulvian Bridge only three emperors ruled the state: Constantine, Licinius and Maximin Daja. The first two formed an alliance in 313 in Milan, which shortly resulted in the defeat of Maximin. Lack of a common enemy, however, made an alliance groundless. Eventually, war broke out between the two rulers in $314 \mathrm{AD}$. Socrates believed that the cause of the war was the persecution of Christians by Licinius, which meant a violation of the provisions of the Milan alliance ${ }^{25}$. Constantine defeated Licinius in the battles of Cybale and Campus Ardiensis. On March 1, 317 a ceasefire was signed. Licinius kept the throne, but had to give Constantine Illirycum and kill his ceasar Valens, nominated just before the battles.

The war broke out again in 321. In 324 Licinius was defeated on land and sea and besieged in Nicomedia. Then he capitulated and gave up the imperial dignity. Constantine assured his safety and sent him into exile to Thessalonica. Shortly after that he was executed, which was justified by Constantine's propaganda about a conspiracy organized by the overthrown augustus ${ }^{26}$.

\subsection{The constitutions of Constantine after the defeat of Licinius}

\subsubsection{General characteristics}

After the defeat of Licinius, Constantine became the sole ruler of the Empire. The defeated augustus was declared a tyrant, or the one who came to power illegally. It was not true. Licinius had an equally or even more legitimate claim to be ruler than Constantine, and they together issued constitutions ${ }^{27}$. To be more

25 Socr. 1,3. Soz. 1,2.

26 Socr. 1,4.

27 It was pointed out by S. Corcoran, op. cit., p. 277-278. 
precise, it should be stated that the tyrant meant a ruler who was overthrown by his successor. Constantine's propaganda effectively attempted to undermine the ousted ruler ${ }^{28}$.

Since Licinius had no legitimacy to govern the state, all his acts were also affected by this defect. The solutions to that issue are the constitutions issued by Constantine and placed at the beginning of Title 14, book XV of the Theodosian Code.

However, modern legal science does not exclude the possibility that codifiers of Theodosius made a mistake dating constitutions and arranging their order within the 14th title. The problem regards constitutions XV, 14, 4 and XV 14,3 . According to notes inserted at the end of each constitution, they were issued in Rome, during the seventh consulate of Constantine and the first consulate of Constantius. Therefore, that would be 326 AD. Thus, they are placed after constitutions issued in the year 324 (CTh. XV, 14,1) and 325 (CTh. XV, 14, 2). Such a date of issue clearly indicates that the term "tyrranus" used in those constitutions refers to Licinius.

German scholar O. Seeck alleged an error was made on the part of the codifiers, proposing in 1929 to date those two constitutions 13 years earlier, i.e. to the year 313 , and thus concluding that they relate to the Maxentius usurpation ${ }^{29}$. Such a presumption is accepted also by M.V. Escribano ${ }^{30}$. The conclusion appears to be correct in relation to the constitution CTh. XV, 14, 4, because it results from its content, while the constitution XV 14,3 may refer to any „tyrant”.

\subsubsection{Constitutions relating to acts of Licinius (CTh. XV, 14,1; XV, 14,3)}

The first constitution, which was enacted on May 16, $324^{31}$ and published shortly after the defeat of Licinius, is maintained in an unambiguous tone. It is based on the opposition between constitutions and laws issued by Licinius on one hand and the old law (ius vetus) and the legislation of Constantine (statuta nostra) on the other hand. The former did not have any legal force and were overturned since they were issued by the tyrant. Only ius vetus and statuta should be observed. It is a revocation of effects of usurpation in the legislative field, the

28 See the works of Socrates and Sozomen (Socr. 1,1-4,Soz. 1,2), which were written one hundred years after the Constantine's victory.

29 O. Seeck, Regesten der Kaiser und Päpste, Stuttgart 1929, p. 286. The same scholar refers the CTh. $\mathrm{XV}, 14,10$ constitution to the Eugenius usurpation, although there is a name of Maximus expressly mentioned.

30 M. V. Escribano, La ilegitimidad..., p. 103 and succ.; idem, Constantino..., p. 316.

31 CTh. XV,14,1; Imp. Constantinus a. ad Constantium p(raefectum) p(raetorio). Remotis Licini tyranni constitutionibus et leges omnes sciant veteris iuris et statutorum nostrorum observari debere sanctionem. P(ro)p(osita) XVII kal. iun. Crispo II et Constantino III caess. conss. 
type of restitutio ad integrum, treating the period of the reign of Licinius as if it were nonexistent ${ }^{32}$.

The second constitution does not have such an absolute character. It should be rather referred to Maximian times, as Seeck proposed. That may explain a much milder tone of that law, in contrast to the previous one. Theodosian codifiers dated it July $8,326^{33}$.

In that constitution, the division between "lawful" and "unlawful" no longer runs in accordance with criteria of usurper legislation - ius vetus and legislation of legitimate augustus. That is because it concerns only what rescripts were issued by the tyrant, so it concerns the imperial rescripts as a form of constitution. Those rescripts that were issued against the law (contra ius), lose their binding force under that constitution, but as noted, due to its own individual character, each rescript, even those issued by a legitimate ruler, should be consistent with the $i_{i s}{ }^{34}$. The constitution accepts that there are rescripts that are legal (legitime) and those remain in force. M.V. Escribano as an example of the provisions contra ius gives Maximus's repressions against the senators, which were annulled by the constitution CTh XV, 14,45. That is (of course) a kind of superfluum. Even without that constitution they would be invalid.

A relation between that constitution and the constitution of CTh. XV, 14, 1 leads us to certain observations. Firstly, they regulate the same matter. At the same time, they are largely contradictory to each other. It can be assumed that Constantine in a span of 2 years between the enactment of those two constitutions (as officially dated), changed his opinion, perhaps induced to do so by the discrediting of legal certainty after the repeal of all of Licinius's constitutions, which, because of the relatively long reign, was probably a lot. So he decided to restore power to some rescripts, imperial responses on specific issues, which were not usually of a strictly political nature.

But equally likely, if the upheld thesis of O. Seeck's is a statement that both constitutions relate to two different "tyrants" and two different usurpations indeed, so in fact they are not contradictory and the dating is a result of an error of the Theodosian codifiers.

32 Cfr. M. V. Escribano, La ilegitimidad..., p. 109.

33 CTh. XV,14,3: Idem a. Antiocho p(rae)f(ecto) vig(i)l(um). Quae tyrannus contra ius rescripsit non valere praecipimus, legitimis eius rescriptis minime impugnandis. Dat. VIII id. iul. Rom(ae) Constantino a. VII et Con stantio caes. conss.

34 S. Corcoran, op. cit., p. 153-154.

35 M. V. Escribano, La ilegitimidad..., p. 106. 


\subsubsection{Constitution relating to judgments passed during the reign} of Licinius (CTh. XV, 14,2)

The activity of Licinius, the emperor as any other, involved not only issuing acts of general and abstract character, but also participating in the civil judiciary. That was due to the rules of the extra ordinem proceeding introduced in the first century (cognitio extra ordine). It spread in the third century, and quickly began to dominate. Initially, it gave legal protection for situations that could not form the basis to an action in the formulary system, but which only were protected by the constitutions of the emperor. In 342 Constantius II and Constans found this procedure to be the only one. It was more flexible and more efficient than the previous system. In an extra ordinem proceeding, however, all judgments were issued in the name of the emperor by imperial officials (initially praetorian prefects and governors, then the special judges) ${ }^{36}$. On the other hand, in the formulary system proceedings were pending before the praetor, a republican official, and a verdict was passed by private judges. So if the emperor was considered a tyrant ( thus a man who illegally seized power) all his judgments could not have binding force. Since his reign was illegal, all decisions issued in his name were defective.

This problem was solved on February 12, 325 by Constantine ${ }^{37}$. That constitution is applicable not only to the tyrant, but to his judges (tyrranus et iudices eius), because they judged in the name of the emperor and on his command. As in the CTh. XV, 14, 3 constitution (as it seems earlier), there is also a division between illegal and legal acts (legitime - illegitime). The former lost their legal force, whereas the latter remained in effect. Which of these acts were issued contra ius and which were legitime, was decided either by a declaratory act of the emperor or it was defined in other constitutions.

\subsubsection{Constitution relating to the degradation of the senatorial state} (CTh. XV, 14,4)

The last constitution of Constantine contained in title 14 of book XV of the Theodosian Code is a constitution dated on July 15, $326^{38}$, on the restoration of

36 Cfr. W. Turpin, Formula, processo and proceedings extra ordinem, "Revue Internationale des Droits de l'Antiquité", $3^{e}$ Série, Tome XLVI, 1999, p. 499-574; W. Litewski, Studia nad rzymskim postępowaniem kognicyjnym, Kraków 1971; idem, Rzymski proces cywilny, Warszawa - Kraków 1988, p. 73-103; W. Wołodkiewicz, M. Zabłocka, Prawo rzymskie. Instytucje, Warszawa 2002, p. 305-311.

37 CTh. XV,14,2: Idem [Constantinus] a. ad universos provinciales. Tyranni et iudicum eius gestis infirmatis nemo per calumniam velit quod sponte ipse fecit evertere nec quod legitime gestum est. Dat. prid. id. feb. Paulino et Iuliano conss.

38 CTh. XV,14,4: Idem [Constantinus] a. ad senatum. Super his, qui ex senatoribus ad navicularium munus a tyranno deiecti sunt ac restitui suis natalibus deprecantur, placuit vestrae sanctitati iudicium examenque mandare, ut vos eligatis, qui splendori vestro patrimonii viribus et honestate vivendi et natalium dignitate respondent. Incongruum est enim tantae dignitatis arbitrium alteri potius quam ves- 
the senatorial status to persons oppressed by the tyrant. The actual text of the Constitution confirms the thesis of the error of the Theodosian codifiers. Licinius had never reigned over Rome, and therefore he could not issue constitutions and decisions affecting the senators ${ }^{39}$, who, though they possessed estates all over the Empire, lived in the City and its surroundings. Such decisions could be more likely issued during the time of Maxentius reigning in Rome, who certainly had to encounter opposition. Socrates coments on the repression against opponents of the power of Maxentius ${ }^{40}$, but of course this may be the effect of Constantine's propaganda designed to justify the war.

This constitution concerns the oppressed senators, which are released from munus naviculare and restores them with all rights of their state (restitui natalibus suis). Constantine put the decision on the readmission of these people to the Senate into the hands of senators. It is an expression of policy that Constantine took over the Senate - at least the formal respect and recognition of its role ${ }^{41}$. Therefore it had to be supplemented on the basis of co-optation, and every decision had to be approved by the Prefect of the City.

The provisions of this constitution, however, are puzzling. M.V. Escribano, as mentioned, sees in it clarification of the provisions of the constitution CTh. XV, 14,3. However, firstly, such clarification is not necessary. Simply - if these decisions were considered to be contra ius they are losing their force automatically. That requires a declaratory decision, and not a constitutive one. The issue of this constitution, however, can be explained by the weight of the discussed issues - the social role of the senatorial state. Regulation of the same issue in two constitutions can be naturally explained by the fact that the constitution CTh. XV, 14,3 was addressed to the prefect vigilum, whereas this constitution concerned the Senate, and therefore (due to the different recipients), the latter is not a superfluum. However, it is important to draw attention to the contradictions in the dispositions of these acts, which - assuming their proper dating by Theodosian compilers - point to the far-reaching inconsistency.

Therefore, accepting the thesis that the discussed constitution refers to the reign of Maxentius, it should be pointed out that, precisely speaking, this law does not invalidate the decision of the overthrown usurper. Otherwise, it should restore senatorial status to all former Senate members. Since it is not made, in fact there is no invalidation of the tyrant's decision, but rather its cancellation.

tris suffragiis sententiisque conmittere. Eorum autem, quos ut dignos elegeritis, nomina $p$ (rae)f(ectus) urbis nobis insinuet, ut vestrum iudicium conprobemus. Dat. id. iul. Constantino a. VII et Constantio caes. conss.

39 The same noticed M. V. Escribano, Constantino..., p. 316.

40 Socr. 1,2 .

41 See D. Schlinkert, Ordo senatorius und nobilitas: Die Konstitution des Senatsadels in der Spätantike, Stuttgart 1996, p. 78-80. 
The Senate itself decided on the restoration of someone to the Senate, so it could happen that someone deprived of a place in the Senate by Maxentius, did not return to it as he was not elected. So in his case, the usurper's decision would remain in force (or at least remained effective). That can be explained by the fact that among the persons removed by Maxentius were also persons not welcomed by Constantine. Such wording of the constitution secured against their return.

\section{Constantius II against Magnentius \\ 4.1. The political situation after the death of Constantine}

At the time of Constantine's death in 337 , he left three sons ${ }^{42}$ : Constantine II, Constantius and Constans ${ }^{43}$ and two grandchildren. Soon after, Constantius, acting with the consent of the brothers absent in Nicomedia, carried out a purge, murdering the surviving members of the imperial family, among them, the grandson of Constantine, Dalmatius, who was caesar from $335^{44}$. Only the grandchildren of Constantine, 12 year-old Gallus and 7 year-old Julian, remained alive.

The three brothers were quickly announced augustuses and divided the state as it had already established by Constantine the Great. Constantine took over Gaul, Spain and Britain, Constans - Italia, Illirycum, Macedonia and Achaia and Constantius - the East. Meanwhile in the West, a conflict about Illirycum broke out between Constantine and Constantius. Constantine was killed in the battle of Aquileia and Constans became the sole ruler of the West ${ }^{45}$. From the beginning, his reign gradually began to be perceived as tyrannical. Accumulated animosity exploded in the night of 18 January 350, at the banquet in Augustodunum (Autun) given by Marcellinus comes rerum privatorum. The commander of the legions Ioviani superiores and Herculano superiores, Magnus Magnentius ${ }^{46}$, was proclaimed emperor. Constans fled to Spain, where was murdered by conspirators in Helena in late February ${ }^{47}$.

42 Socr. 1,38-40, Soz. $2,34$.

43 On their reigns see: M. Di Maio Jr., R. Frakes, Constantine II, http://www.roman-emperors.org/conii. htm, idem, Constatnius II, ibidem, idem, Constans, ibidem, Constantine II, Constatius II, Constans, [in:] ERE, Empirehttp://www.roman-empireEmpire.net/collapse/collapse.html; hasła: Constantine II, Constatius II, Constans, [in:] OCD, Konstantyn II, Konstacjusz, Konstans, [in:] Słownik cesarzy rzymskich, Poznań 2001. About Constantius II see also: Amm. Marc. mainly book 20.

44 Socr. 2,25,264.

45 Socr 2,5, Soz. 3,5 .

46 See: M. Di Maio, Magnentius (350-353 A.D.) and Decentius (351-353 A.D.), http://www.romanemperors.org/magnent.htm,: Magnus Magnetius, [in:] ERE i OCD; I. Didu, Magno Magnenzio. Problemi cronologici ed ampiezza della sua usurpazione. I dati epigrafici, "Critica Storica" 1977, 14, p. 11-56.

47 Such version is presented by M. Di Maio, op. cit.; contrary to it: A. Ziolkowski, footnote no. 125, book II [in:] Sokrates Scholastyk, Historia Kościoła, Warszawa 1986, p. 205 - who dates the death of 
The Prefect of the City accepted the authority of the usurper and he was followed by Africa and Cyrene, which was subordinate to Constantius. Constantius could not react quickly enough because of the war with Persia ${ }^{48}$. The decisive battle took place in August 351, near Mursa in Pannonia, where the usurper's army was completely destroyed. Magnentius withdrew to Gaul, where he hoped to gather the troops but on June 3,353 Constantius defeated him at Mons Seleuci ${ }^{49}$.

\subsection{The Constitution of Constantius II and Constans (CTh. XV, 14,5)}

Even before the final defeat of the usurper, but already a year after the battle of Mursa, when the fate of the war was predetermined Constantius II and Constans Caesar issued in Milan on November 3, 352 a constitution relating both to the legal actions of the Magnentius and other legal actions, which were made during his reign ${ }^{50}$.

By virtue of this constitution everything that the usurper or his judges issued "against the law" (contra ius statuerunt) was annulled. The obligation to return appropriated propertywas formulated separately. The role of ownership (especially of land), although contained in the concept of ithe nvalidation of everything that had been issued illegally, required a separate and special emphasis. The usurper who tried to crush his opponents, especially after defeating Nepotianus, lavished with death sentences as well as confiscation of property ${ }^{51}$. Repressions probably also met many supporters of the legitimate emperor Constantius, whose estates were in the territory subjected to the power of the usurper. Perhaps that provision was also concerned with all the expropriations, which were in the interest of the usurper, although made in accordance with the law.

The invalidation of what Magnentius issued contra ius, did not mean that the recognition of the entire output of usurpation as invalid. On the contrary, it is suggested that there were actions (and probably court judgments) that "the

Constans on January 18, and supposes that only after hisare unclear death, Magnentius was declared emperor. About Constans death unclearly Socrates and Sozomen - Socr. 2,25, Soz. 4,1, however Sozomen suggests Magnentius' leadership in the conspiracy from its the beginning. See also S. Mazzarino, L'Impero romano, Roma - Bari 1973, p. 702-703.

48 Zos., II 42-54. See also T. Kotula, Uzurpator Magnencjusz a ludność prowincji, [in:] Studia $z$ dziejów antyku. Pamięci Profesora Andrzeja Kunisza, red. W. Kaczanowicz, Katowice 2004, p. 232-242 and literature indicated there.

49 Socr. 2,32, Soz. $4,7$.

50 CTh. XV, 14,5: Imp. Constantius a. et Constans c. ad universos provinciales et populum. Quae tyrannus vel eius iudices contra ius statuerunt, infirmari iubemus reddita possessione expulsis, ut qui vult ab initio agat. Emancipationes autem et manumissiones et pacta sub eo facta et transactiones valere oportet. Dat. III non nov. Med(iolano) Constantio a. V et Constante conss.

51 Por. T. Kotula, op. cit., p. 240. 
tyrant and his judges" made under the law. Constantius ordered the recognition of the validity of emancipations, liberations and contractual obligations (such as pacta and obbligationes). It has multiple explanations. Firstly, it was required by the certainty of legal transactions, public order and sense of justice. Secondly, the civil law issues also were governed mainly by ius vetus and older constitutions, so these activities were not contra ius. And thirdly, civil law actions were not made on behalf of either the usurper or his usurpation ${ }^{52}$.

\section{Usurpation of Magnus Maximus}

\subsection{The origin and the course of the usurpation}

On August 9, 378, the emperor Valens, without waiting for the western army of Gratian, hit the Goths at Adrianople. Instead of the expected victory, which he did not want to share with the ruler of the West, he met disaster. Forty thousand Roman soldiers, among them the emperor himself, fell on the battlefield ${ }^{53}$.

The defeat at Adrianople finally deprived the Empire of a military initiative ${ }^{54}$, further increasing its threat. In this situation, Gratian, who had no commanding talents, gave the command in the hands of Theodosius, the son of magistrum equitum praesentalis of Emperor Valentinian I, called for this purpose from Spain. Soon after, on January 19, 379, Gratian appointed Theodosius Augustus in the East.

Gratian was a supporter of Nicene orthodoxy, which sooner or later had to result in conflict with the pagan aristocracy. In 382, at the request of Bishop Ambrose of Milan, Gratian removed the Altar of Victoria from the Senate chamber and revoked state subsidies for many forms of pagan worship. In response to the protest of the Senate, Gratian renounced also the title pontifex maximus. According to Zosimos, then one of the senators said that there would be another pontifex maximus in a short time ${ }^{55}$. The first usurper, however, was a Nicene orthodox supporter, who went down in history with, among other things, a death sentence on the heretic Priscillian.

In the spring of 383 troops stationed in Britain renounced obedience to Gratian and announced Magnus Maximus as the emperor ${ }^{56}$. Maximus was comes

52 Por. M. V. Escribano, La ilegitimidad..., p. 111-112.

53 Amm. Marc. 31.12.1-17; 13.1-19.

54 This is an opinion of A. Ziółkowski, Historia Rzymu, Poznań 2005, p. 548.

55 Zos. 4.36.1-5.

56 See: W. E. Roberts, Magnus Maximus http://www.roman-emperors.org/madmax.htm, Maximus Magnus, [in:] ERE, New York 1992; Magnus Maximus, [in:] OCD, Magnus Maksymus, [in:] Słownik..., Poznań 2001; C. Torres Rodriguez, Magno Clemente Maximo, Santiago 1945; W. Ensslin, Maximus, Roman Empire XIV, 1930, kol. 2546-2555; J. R. Palanque, Lempereur Maxime, [in:] Les 
britaniarum from 379, and from 380 magistrum britaniarum ${ }^{57}$ (maybe he got that promotion earlier, in 376 respectively ${ }^{58}$ ). The reasons for the rebellion are not completely known. Perhaps Maximums was unwilling to be a legitimate emperor or count on his kinship with Theodosius ${ }^{59}$. The army quickly turned away from the unpopular Gratian, who was killed at Lugdunum (Lyon) by magister equituum of Maximus, Andragatios, presenting himself as a supporter of the legitimate emperor ${ }^{60}$.

The usurper sought to legitimize his power. Perhaps he count on taking custody over minor Valentinian. Finally, in 384 agreement was reached, under which Maximus was considered the emperor in return for the recognition of the power of Valentinian in Italia, Africa and Illirycum. Nevertheless, even in the same year Maxiumus appointed his son Victor to the dignity of augustus, thereby revoking its recognition for Valentinian $\mathrm{II}^{61}$.

In 387 Maximus, under the pretext of aid in the defense of Pannonia, which was threatened by invasions of the barbarians marched into Italia, and - rather than going to the fighting line - moved towards Aquileia, where the court of Valentinian resided ${ }^{62}$. The emperor with his mother Justine was forced to withdraw to Thessalonica and ask the emperor of the East for help. Both augustuses launched a joint operation against the usurper. He suffered a defeat at Emona Siscia and Poetovio in Illirycum. Theodosius and Valentinian troops came across the Alps and captured Maximus in Aquileia ${ }^{63}$. Despite pleas for mercy, he was executed in August 388 at Aquileia ${ }^{64}$.

Empereurs romains d'Espagne, Paris 1965, p. 255-267. On the usurpation and Maximus's efforts to legitimate his power, see M. V. Escribano, Usurpación..., p. 257-272.

57 W. E. Roberts, op. cit.

58 A. Ziółkowski, op. cit.

59 His relationship with Theodosius the elder (father of the emperor) is not clear. Probably his distant relationship was rather a clientele (W. E. Roberts, op. cit.). See also A. Ziółkowski, footnote. 43, book V [in:] Sokrates, p. 409, Maximus Magnus, [in:] ERE and P. Brown, Power and Persuasion in Late Antiquity: Towards a Christian Empire, Madison 1992, p. 104.

60 Theod. 5,12-15; Socr. 5,11,596. According to Socrates, Andragatios hiding himself in the litter (Sozomen writes of the "carriage"), ordered to spread widely gossip abount Leta, wife of Gratian and newly married to him. When the Emperor approached the litter, Andragatios jumped out of it and killed him. S. Mazziarino believes, however, that Gratian was first captured and then executed (S. Mazzarino, Impero..., p. 735), similar: V. Marotta, [in:] Storia di Roma, v. 3, p. 1. L'Età tardoantica; I crisi e transformazioni, Torino 1993, p. 567 and M. Jaczynowska, M. Pawlak, Starożytny Rzym, Warszawa 2008, p. 377.

61 See W. E. Roberts, op. cit.; ERE dates the nomination of Victor on 387 (Maximus Magnus, [in:] ERE).

62 Zos. IV.42-43.

63 Socrates says that he was betrayed by his own soldiers: Socr. 5,14,600.

64 OCD. indicates a date of August 27 (Magnus Maximus, [in:] OCD, W. E. Roberts - August 28 (W. E. Roberts, ibidem), similarly ERE (Maximus Magnus) and A. Ziółkowski, footnote no. 61, book. 5, op. cit. 


\subsection{Abrogation of the legal consequences of Maximus usurpation}

\subsubsection{Invalidation of dignity given by Maximus}

(CTh. XV, 14,6; XV, 14,8)

During his reign Maxiumus used all the prerogatives of the emperor: he minted coins, issued constitutions, gave dignity and functions. After defeating Maximus, the victorius emperors (in fact, Theodosius himself) faced the issue of how to react to those nominations.

The first constitution relating to this matter was an act issued by the emperors Valentinian, Theodosius and Arcadius ${ }^{65}$ on September 22, 388 in Aquileia, addressed to Trifolian, praetorian prefect of Italia ${ }^{66}$.

Exercising their powers as emperors (or rather Theodosius himself ${ }^{67}$ ), the act invalidated all the nominations made by the usurper, at the same time restoring for everybody the status, which they occupied prior to the Maximus rules (pristinum statum). The constitution proves a soft approach to Maximus supporters. Instead of punishment, a sort of amnesty was given (the aforementioned restoration of a pristinum statum). As an example Socrates described the case of Quintus Aurelius Symmachus, prefect of the City, Maximus supporter and pagan who was acquitted of the charge of lese-majesty by Theodosius (according to Socrates, when he sheltered in the church) ${ }^{68}$.

Calling and proclaiming Maximus a tyrant (tyrranica audiacia) is distinctive. Meanwhile, he benefited from the rights that Theodosius recognized in the agreement of 384 . Acts nominating for dignities (honores), which were repealed by the discussed constitution, were legal ${ }^{69}$. The term "the tyrant" adopted by the constitution is of a technical nature, and means "one who seized power illegally"70, or more precisely: "the ruler who was overthrown".

Four months later, on January 14, 389, the same augustuses issued in Milan the next constitution addressed directly to Constantine, praetorian

65 Arcadius was declared augustus in January 383 - Socr. 5.12, Soz. 7,12.

66 CTh. XV,14,6: Imppp. Val(entini)anus, Theod(osius) et Arcad(ius) aaa. Trifolio p(raefecto) p(raetori) o. Nullus sibi honorem audeat vindicare, quem tyrrannica concessit audiacia, sed ad pristinum statum damnata praesumptio revocetur. Dat. X kal. Octob. Aquil(eiae) Theod(osio) a. II et Cynegio conss.

67 During that time, Arcadius was 9 or 10 year-old and Valentinian was 17 year-old. Thus, Theodosius should be considered the actual ruler of the entire Empire and the author of solutions adopted in the discussed constitutions .

68 Socr. V,14. Socrates was wrong here, however, when he writes that at the time Symmachus was consul and princeps senatus. In fact, he did not become consul until 391. During Maximus reign he was a prefect of the City in the year 384/385. However, there is proof that Theodosius limited his decision to the cancellation of the appointment of the usurper, and let the offenses go into oblivion. About the right of asylum in that period see W. Mossakowski, Azyl w późnym Cesarstwie Rzymskim, Poznań 2000.

69 Cfr. M. V. Escribano, La ilegitimidad..., p. 104, 113.

70 M. V. Escribano, La ilegitimidad..., p. 103. 
prefect of Gaul ${ }^{71}$. This act consists of two parts. The first is a continuation and clarification of the Aquileian constitution. It obliged those who accepted the dignities (dignitas) during the usurpation to disclose and return the nominating papers (codicillos adque epistulas et promere et reddere). It is a kind of executive act in relation to the previous constitution declaring the cancellation of grants and promotions. As a consequence, it was guaranteed that nobody would be able to invoke such a promotion in the future. The second part of the discussed constitution concerns the judgments and acts of private law executed during the time of the usurpation (see below).

\subsubsection{The issue of legal actions and judgments passed during the usurpation (CTh. XV, 14,7; XV, 14,8; XV, 14,10)}

During the reign of Maximus, on the territories subjected to him, existed, of course, wide economic and legal relations: contracts were concluded, other legal actions were made, lawsuits were brought. They were largely based on law common for both parts of the Empire, especially on ius vetus. Only a small degree of them could be governed by the laws of the usurper. The relatively long period of the Maximus reign (5 years) meant that after his fall the victorious emperor had to consider the problem of how to react to this issue. A need to ensure the certainty and order of the legal system, which in case of a cancellation would be certainly affected, supported the decision to leave them in force. Also, practical considerations favored upholding the validity of legal acts and judgments made or issued during usurpation. The problem of legal actions was relatively clear. Since they were carried out on the basis of law common to the entire Empire, there were usually deprived of a political nature ${ }^{72}$, similarly in the case of the judgments. They were also issued on the basis of legal and universally recognized legislation. Their repeal would violate public order and the sense of justice, and would create the need of revision of all cases, which in turn would cause serious problems for the courts. Those matters lead to the recognition of judicial decisions as valid.

71 CTh XV,14,8: Idem aaa. [Valentinianus, Theodosius et Arcadius] Constantino p(raefecto) p(raetori)o Galliarum. Omnes, qui tyranni usurpatione provecti cuiuslibet acceperunt nomen illicitum dignitatis, codicillos adque epistulas et promere iubemus et reddere. Iuris quoque dictionem adque sententias, quas promere nequiverunt qui iudicum nomen habere non potuerunt, ex omnibus publicorum monumentorum scriniis iubemus auferri, ut abolita auctoritate gestorum nullus his iudicatis conetur inniti, quae et tempore et autore delentur. Exceptis his tantum negotiis adque in sui integra firmitate mansuris quae conventionibus pactasque finta sunt, si dolo metuve caruerunt: his quoque parter exceptis, quae donatio transtulit, emancipatio liberavit, contulit manumissio praemia meritae servitutis, quia in his omnibus voluisse sat iuris est. Dat. XVIIII kal. Feb. Med(iolano) Timasio et Promoto vv. cc. conss.

72 It can not be excluded that some of these activities were been made under duress for example, but most of the effects in private law was rather done via public law (e.g., expropriation). 
But the problem, as in the case of previous occasions, lay in the extra ordinem proceedings. From 342, it was the exclusive procedure. All judgements were issued in the name of the emperor. So if the ruler was the usurper, he was not in fact entitled to issue them, and in fact they were all non-existent.

Two constitutions made an attempt to resolve this problem. One of them was issued in Milan on October 10, 388 $8^{73}$. By virtue of its provisions, all judgments issued in breach of the law (non iura reddendo) were cancelled. That relates to the matter of violation of ius vetus and leges of legal emperors, rather than the laws issued by Maximus. The other constitution - issued on January 14, 389 - confirmed the cancellation of judicial decisions and additionally ordered to remove all references to them from public buildings (ex omnibus publicorum monumentorum scriniis iubemus auferri). It is one of the most precise constitutions in legal terms ${ }^{74}$. However, reasons of legal security, order and justice required keeping in force legal acts that were concluded in large number in everyday legal transactions. Therefore, pursuant to this constitution, enumerated legal actions were considered to be, as an exception, valid. Among them were contracts and pacts (conventionis pactisque), which provisions had been fulfilled by both parties, if they were not concluded under deception or coercion (si dolo metuve caruerunt) ${ }^{75}$, fulfilled donations (donatio), emancipations from the power of pater familias and the liberation of slaves (manumissiones). It is also worth noting that judgments that "were not worthy of this name" (nomen habere iudicum qui non potuerunt) were revoked. As a result, it is possible either to assume that all judgments issued during the time of usurpation were treated as having such a characteristic, or - more likely - that the constitution adopted the mechanism applied in the CTh. XV, 14, 5 constitution, dividing the judgments to those issued in accordance with the laws and those that were contrary to the law.

The last question related to the usurpation of Maximus was settled by the sons of Theodosius, Arcadius and Honorius, in the constitution of April $26,395^{76}$, according to which premises (fundi perpetui) granted to adherents

73 CTh. XV,14,7: Idem aaa. [Valentinianus, Theodosius et Arcadius] Trifolio p(raefecto) p(retori)o. Omne iudicium quod vafra mente conceptum iniuriam, non iura reddendo Maximus infandissimus tyrannorum credidit promulgandum, damnabimus. Nullus igitur sibi lege eius, nullus iudicio blandiatur. Dat. VI id. Octob. Med(iolano) Theod(osio) a. II et Cynegio conss.

74 T. Honoré, op. cit., p. 186.

75 In fact, this clause is not needed. Roman law recognized deception (dolus) and the compulsion (metus) as saying, in today's language, a defect of declaration of will, that was self-sufficient to undermine the agreement. The purpose of this reference was probably to emphasize that, first of all, obligations that were concluded under the deception of the usurper or his officials do not gain validity.

76 CTh. XV,14,10: Idem aa. [Arcadius et Honorius] Eulogio c(omiti) r(erum) p(rivatarum). Qui tyranni Maximi secuti iussionem fundos perpetui iuris non ab ordinariis iudicibus, sed a rationalibus acceperunt, eorum amissione plecantur adque ad rem privatam denuo revertantur. Dat. VI kal. Mai. Med. 
of the usurper were taken back and became the imperial property (res privata $)^{77}$.

On the basis of these constitutions, the illegality of rules of the usurper as well as his lack of power to either make changes in the political status of citizens, or judge them were emphasized. Also it was ensured that the supporters of the usurpation would not hold appointments and dignities and would not be able to benefit from what they had acquired during the usurpation by legal acts, using their privileged position. On the other hand, by keeping in force obligations, liberations and emancipations, the core of economic and legal relations (and also, perhaps, a large number of judicial decisions) was left intact, the confidence in the state was sustained and the emperors and their judges were dispensed from re-examining judicial cases. The average citizen of the Empire probably did not suffer major inconvenience (at least from a legal point of view) connected with the change of the augustus ruling in Britain, Gaul and Spain.

\section{Usurpation of Eugenius 6.1. Position of Arbogast}

After defeating Magnentius, Theodosius left in Italia his commander and close collaborator Arbogast, who had served as magistrum militum since 388 . Officially he was subjected to Valentinian II, but in fact, he was nominated by Theodosius with the task of taking care of the young ruler of the West. Arbogast quickly gained a dominant position on the court in Vienne (where Valentinian resided) so that he became de facto a ruler of the West ${ }^{78}$. After one of the clashes between Valentinian and Arbogast, on May 15, 392, the emperor was found hanged in his bedroom.

The circumstances of the death of the emperor provoked controversies. Arbogast was accused of murdering the emperor ${ }^{79}$, however, suicide could not be excluded ${ }^{80}$. The murder of Valentinian was not in the interest of Arbogast. Being a Frank he could not expect the imperial purple, whereas the incapacitated Valentinian was the ideal legalization of his reign. He could not know who would

(iolano) Olybrio et Probino conss. R. Sanz connects this constitution with the rehabilitation priscillianists, R. Sanz Serrano, Aristocracias paganas en Hispania Tardía (S. V-VII), "Gerión” 2007, vol. extra, p. 455. See also: T. B. Zardini, Usurpação, identidade e poder no século IV d.C. A construçãa da imagem imperial de Teodósio no confronto com Máximo e Eugênio, Vitória 2008, p. 68-69.

77 See: R. Sanz, Aproximación al estudio de los ejércitos privados en Hispania durante la antiguedad tardia, "Gerión" 1986, no. 4, p. 233.

78 Zos. 4, 53; Soz. 7, 22.

79 Sokr. 5,25,652; Zos. 4, 54, 3.

80 Soz. 7, 22. Such a conclusion prevails in the modern historiography, cfr. A. Ziółkowski, footnote 107, book V, Sokrates, op. cit. 
be his successor and whether Theodosius himself would decide to deal with the affairs of the West. To keep the power he had to forestall the ruler of the East and appoint a new emperor (on his own).

Arbogast hesitated to take any action after the death of Valentinian. But finally on October 22, 392, in Lungudum Christian Flavius Eugenius ${ }^{81}$, a former head of the imperial chancellery (magister scriniorum), was proclaimed augustus. Perhaps Arbogast hoped that the candidacy of Eugenius instead of himself would be easier to accept to Theodosius as well as it would provide him the support of the pagan senatorial aristocracy of Rome. Initially Theodosius behaved passively and only in January 393 declared his son Honorius augustus ${ }^{82}$, which was equivalent to a refusal to recognize Eugenius. Theodosius moved against the usurper and defeated him on 5 and 6 September 394, in the two-day battle of the Fridigus river ${ }^{83}$, what Christian writers attributed to divine intervention in support of the army of the Church against pagans ${ }^{84}$.

\subsection{Constitutions of the sons of Theodosius ordering the legal situation after the fall of Eugenius}

\subsubsection{Attitude to the legal activities of the private law (CTh. XV, 14,9)}

Theodosius died on January 17, 395 $5^{85}$, just 4 months after the suppression of the usurpation which supposedly was foretold to him by an Egyptian monk ${ }^{86}$. The burden of canceling the legal consequences of Eugenius's usurpation fell on his sons: Honorius, announced augustus in January 393, reigning in the West, and Arcadius who was augustus from already 383 and who received the eastern part of the Empire.

The first constitution, that regulates those matters, was issued on April 21, 395 in Milan ${ }^{87}$. It introduced a very clear distinction between the time of the

81 On Arbogast and Eugenius see Arbogast, Eugenius Flavius, [in:] OCD, Arbogast, Eugenius Flavius, [in:] ERE; W. E. Roberts, op. cit.; S. Więckowski, Z dziejów ostatniej reakcji pogańskiej w Rzymie, „Przegląd Klasyczny” 1937, nr 3, p. 27-78; K. Kęciek, Początek odrodzenia pogańskiego na Zachodzie i śmierć Walentyniana II, „Przegląd Historyczny” 1990, nr 81, p. 377-403.

82 Socr. 5,25,652, Zos. 4.55; 57; Theod. 5,24.

83 See: P. Janiszewski, Żywioły w stużbie propagandy, czyli po której stronie stoi Bóg. Studium klęsk i rzadkich fenomenów przyrodniczych u historyków kościoła IV i V wieku, [in:] Chrześcijaństwo u schyłku starożytności: studia źródłoznawcze, red. T. Derda, E. Wipszycka, t. 3, Kraków 2000; idem, Eunapius of Sardis and the Solar Eclipse during the Battle on River Frigidus, [in:] T. Derda, J. Urbanik, M. Węcowski (ed.), Euergesias Charin, Studies presented to Benedetto Bravo and Ewa Wipszycka by their Disciples, Warsaw 2002, p.71-85.

84 Socr. 5,25,653; Soz. 7,24. Zosimos presents Different view on Battle of Fridigus (Zos. 4,54,14).

85 Socr. 5,26,655; Theod. 5,25.

86 According to Sozomen (Soz. 7.22, 7.29), this monk had foretold the emperor that he would defeat the usurper, but die soon afterwards in Italia. See also Theod. 5.24.

87 CTh. 15,14,9: Impp Arcad(ius) et Honor(ius) aa. Andromacho p (raefecto) U(rbi). Valeat omnis emancipatio tyrannicis facta temporibus; valeat a domini concessa libertas; valeat celebrata et actis quibuslibet inserta donatio; valeat deficientium omne iudicium; valeat universa venditio; valeant sen- 
tyrant (tyrranicis temporibus, scaevis temporibus) and the times of legitimate rulers (tempus legitimus) ${ }^{88}$. It referred mainly to the legal actions of the private law keeping them in force, demonstrating in that way a high level of legal culture ${ }^{89}$. Simultaneously it was distinctive, in that Theodosius never recognized Eugenius as a legitimate ruler ${ }^{90}$. The needs of the legal circulation prevailed over a narrowly understood legalism. Thus the validity of emancipations, liberations (made by a master, which may indicate that at the time of usurpation, the usurper liberated slaves against the will of their owner), donations, sales, judgments of private judges appointed by the parties, agreements and obligations, wills and inheritance (either according to ius civile - hereditas or pretorian law - bonorum possesio), the establishment of procurators, tutors and curators were recognized. Also procedural actions remained valid - restoration to the previous state (restitutio in integrum), rei vindicatio, sacramentum. As a result, as it was underlined in the constitution, all the actions that were not made by fraud, violence or fear (aut circumscriptio subveniet aut vis aut terror) remained in force.

\subsubsection{Attitude to conferred dignities by the usurper (CTh. XV, 14,9; XV, $14,11 ; X V, 14,12)$}

The Constitution on April 21, 395, apart from dealing with legal actions of the private law, dealt with public issues. It made invalid all consuls, who had served at the time of the usurper (funesti consules). Their names were to be removed from the lists. They should be replaced by the magistrates from the East. Therefore, the assumption was, a contrario, that appointments to other offices, including the office of praetorian prefect, were maintained in force ${ }^{91}$.

tentiae iudicum privatorum - convelli enium iudicium non oportet - quos partium elegit adsensus et compromissi poena constituit; valeant conceptae sollemniter pactiones, valeant scripturae, quibus aut fides rerum aut ratio probatur aut debitum, valeant apud quemlibet habitae spontaneae professiones; valeat deposita super instituenda lite testatio; valeat impetratio iuris communium liberorum; valeat procuratio scaevis mandata temporibus; datus tutor vel curator optineat firmitatem; valeat in sponsam perfecta largitio; doli ac vis ac metus inchoata actio in tempus legitimum perseveret bonorum admissa possesio et adfectus adeundae hereditatis obtineat et interdicti beneficium non amittat; valeat in integrum restitutionis petitum auxillum; valeat vindicatio... identidem desiderata tribuatur; locatio et conductio inviolabilem obtineat firmitatem; interdicti beneficia tempora infausta non mutilent; postulata inofficiosi actio et inmodicarum donationum rescissio petita servetur; beneficia transacta non titubent; sacramento terminata permanean; pignoris adque fiduciae obligatio perseveret. Stent denique omnia, quae in placitum sunt deducta privatum, nisi aut circumscriptio subveniet aut vis aut terror ostenditur. Funestorum tantum consulum nomina iubemus aboleri, ita ut his reverentia in lectione recitantium tribuatur, qui tunc in Oriente annuos magistratus victuris perpetuo sunt fascibus auspictati; tempus vero ipsum, ac si non fuerit, aestimetur, si quidem tunc temporis omissa aliqua praescriptio taciturnitatis etiam de illis, quae confirmavimus, non possit obponi. Dat XI kal. Mai. Med(iolano) Olybrio et Probino conss.

88 See: M. V. Escribano, La ilegitimidad..., p. 115 and succ.

89 T. Honoré, op. cit., p. 214-214.

90 It was pointed out by T. Honoré, op. cit., p. 59.

91 T. Honoré, op. cit., p. 65. 
Nevertheless, it should be noted, that a separate legal act is devoted to the issue of dignities and appointments made by the usurper.

It was the constitution of May $18395^{92}$, in which the two emperors referred to the dignities conferred by the usurper. First of all, they upheld their father's regulation on this matter. It probably applies to the constitution on 14 January 389 (CTh. XV, 14, 8) relating to the Maximus usurpation. Arcadius and Honorius, referring to the persons who at the time of the tyrant (tyranni tempore) received dignities or offices, and also were punished with infamy ${ }^{93}$, uphold the validity of all offices and dignities (dignitas), which were given before the time of usurpation, what to some meant rehabilitation and to others - degradation ${ }^{94}$. The significance of this constitution is disputed. It is surprising that the hypothesis of one legal norm refers to persons qui tyranni tempore militavit vel etiam qualibet administratione donatus est aut honoraria dignitate perfunctus vel quicumque in aliquo honore diversis locis aut exactionibus praefuerunt and people punished with infamy. Therefore, S. Mazzarino ${ }^{95}$ considers this constitution as an act of amnesty in relation to persons punished by the constitution of C.Th. XV, 14,9 . On the contrary B. Sitek believes that the revocation of infamy concerns the officials persecuted by the imperial usurper ${ }^{96}$. Taking into account the content of the constitution and its consistency we should accept the view of the former - this law restores the state before the usurpation as regards both the benefits or burdens imposed by a tyrant. It can be explained (as S. Mazzarino did) with the evolution of tactics of the imperial government (especially Stilicho) to the Senate and the Roman aristocracy, which - as an en masse - supported the usurpation of the pagan Eugenius (see below).

A constitution enacted only a month later (June 17,395$)^{97}$ was a consequence of the aforementioned constitution. It was issued as a result of persecutions made

92 CTh. XV,14,11: Idem aa. [Arcadius et Honorius] Andromacho p(rafecto) U(rbi). Fas est sequi nos paternae dispositionis arbitrium adque ideo universos cuiuslibet ordinis viros, de quibus lex nostra reticuerat, ad veniam volumus pertinere et beneficia inopinantibus ultro deferimus, sancientes hac lege, ne is, qui tyranni tempore militavit vel etiam qualibet administratione donatus est aut honoraria dignitate perfunctus vel quicumque in aliquo honore diversis locis aut exactionibus praefuerunt, notam infamiae sustineant, aut deformi vocabulo polluantur. Quibus eas tantum dignitates valere decernimus, quas ante tyrannicum tempus habuerunt.Dat. XV kal iun. Med(iolano) Olybrio et Probino conss.

93 Roman infamy, as opposed to medieval, does not constitute outlawing. It was only a stain on the honor of a person and resulted in a restriction of legal capacity. A person affected by it could not be a witness to the ceremonial activities, procurator and cognitor, for exemple. (W. Wołodkiewicz, M. Zabłocka, op. cit, p. 114).

94 See also D. E. Trout, Paulinus of Nola, Berkeley - Los Angeles - London 1999, p. 112.

95 S. Mazzarino, Il basso impero. Antico, tardoantico ed èra costantiniana, vol. 1, Roma - Bari 1975, p. 378.

96 It seems that B. Sitek had this constitution in mind when was writing about a prior constitution C.Th. XV, 14,12: B. Sitek, op. cit, p. 230.

97 CTh. XV,14,12: Idem aa.[Arcadius et Honorius] Eusebio p(raefecto) p(retori)o. His quos tirannici temporis labes specie dignitatis infecerat, inusate maculae omnes abolemus infamiam. Cunctis igitur 
by the usurper, which affected significant part of the population ${ }^{98}$. To all those who lost their dignities on the decision of the usurper of infamy, lying on them, was repealed, but only if it was imposed for political reasons ${ }^{99}$. All were restored to the previous state (status prior), i.e. the state which they possessed before the usurpation, and the dignities held by them were recognized. At the same time, this constitution upheld the illegality of granting dignities by Eugenius, stressing that its purpose is to prevent the supporters of the usurper from relying on honors received during usurpations. It should be noted that the said act was an expression of far-reaching legislative inconsistency. Since - in the sense of public law - the whole period of usurpation was treated as non-existent (consuls were removed from lists, damnatio memoriae of Eugenius was made ${ }^{100}$ ), there was no need to restore the victims of repression to their prior status. A general statement that actions of the tyrant did not have legal force would be enough. Therefore, the discussed constitution should be treated as an act of a declaratory nature, ordering issues of social status after the usurpation (which is also suggested by the last sentence of the constitution), and not a constitutive act.

Thus, both sons of Theodosius applied a similar policy to his father. Recognizing the validity of legal actions taken during usurpation, at the same time they invalidated all acts of nominations for dignities and offices. Removal of consuls from the lists constituted a sign of outlawing usurpation under the public law.

\section{Usurpations during Honorius and Theodosius II rules 7.1. Political situation after the death of Theodosius the Great}

Theodosius the Great left two sons, Arcadius and Honorius, who at the time of the death of his father had titles of augustuses. Stilico, magister militum and patrician, became a tutor of Honorius, and, by his own testimony, also Arcadius.. In August 410, Stilicho was murdered in a camp of Honorius army at Ticinum (Pavia) in an antigermanic riot inspired by Olimpius, the imperial secretary ${ }^{101}$. At the same time Alaric entered to Italy. He laid siege to Rome, but withdrew

statum priorem sine cuiusquam loci aut ordinis exceptione tribuimus, ut utantur omnes iure communi, teneant statum veteris dignitatis, ita ut nihil sibi ex his quos adepti fuerant honoribus blandiantur. Dat. XV kal. Iul. Med(iolano) Olybrio et Probino conss.

98 Cfr. B. Sitek, op. cit., p. 230-231. Implementation of the Stilicon policy of alliance with the Roman senatorial aristocracy is indicated as the purpose of issuance of this constitution, see: A. Marcone, L'ultima aristocrazia pagana di Roma e le ragioni della politica, "Incontri triestini di filologia classica" 8 (2008-2009), p. 102. Different view is present ed by T. Honoré, op. cit., p. 213-214.

99 B. Sitek, op. cit., p. 231.

100 B. Sitek, op. cit., p. 229.

101 Soz. 9,4. 
from the City for the ransom. Honorius, however, being under the influence of the antigermanic party, was not willing to fulfill the provisions of the armistice and recognized Constantine as on usurper. In response to that, Alaric forced the Senate to proclaim Priscus Attalus, prefect of the City, the Emperor, who immediately appointed Alaric as magister militum. The Emperor held his dignity shortly, since he quarreled with Alaric refusing to support an expedition to Africa, where the local administrator, Heraclian (killer of Stilicho) remained faithful supporter of Honorius. The German counted on an agreement with the legitimate emperor, but seeing no hope for it, on August 24, 410, he seized and sacked Rome.

Soon after, the Emperor made himself unpopular with his ally Heraclian issuing laws against the Donatist schism widespread in Africa. As a result, coming from Africa, Heraclian proclaimed himself the emperor and leading a huge fleet crossed the Mediterranean Sea and landed at the mouth of the Tiber River. Defeated at Ocriculum, he fled to Africa, but was captured and beheaded in Carthage.

\subsection{The Constitution on August 3, 413 (CTh. XV, 14,13)}

Heraclian's usurpation was short-lived and was quickly suppressed. This does not mean that it did not leave behind any traces. A constitution adopted on August 3, 413 $3^{102}$ demonstrates exactly the opposite. Although the problem concerned only the western part of the Empire and relations between Ravenna and Constantinople were not ideal, a semblance of unity was retained: the constitution was issued on behalf of both emperors - Honorius and Theodosius II.

Among constitutions contained in the title De infirmandis, it has the most radical tone. The usurper, after his death, was sentenced to damnatio memoriae (Heracliani vocabulum nec privatim nec publice ulla memoria teneat). This meant that his name and any mention of him would be erased from all inscriptions, official acts etc., even if it had been made before the usurpation. In this case, it was banned to keep not only public but also private memory.

The Constitution does not grant the validity of any act performed at the time of usurpation. This is an unprecedented decision - such a drastic method

102 CTh. XV,14,13: Impp. Honor(ius) et Theod(osius) aa. Hadriano p(raefecto) p(raetori)o. Heracliani vocabulum nec privatim nec publice ulla memoria teneat, ideoque submovenda esse censemus, quaecumque sub eo gesta esse dicuntur. Libertates quoque, quoniam certum est scelere eius sollemnitatem, consulatus esse pollutam, in melius revocamus, sciatque dominorum voluntas iterandum esse, quod illo auctore advertit stare non posse; semel tamen mutate condicionis beneficium inplendum esse praecipimus et ita repeti manumissionum consuetudines nunc iubemus, ut nullus sub hac occasione incipat nolle quod voluit. Dat. III non. Aug. R(a)v(ennae) post. cons. Honor(ii) VIIII et Theod(osii) V aa. 
was not used after any existing usurpation. It relates in detail to liberations, invalidating all of them and ordering their repetition. This is perhaps due to the fact that Heraclian liberated slaves against the wish of their owners, for example, conscripting them into his army (as did Stilicon in 405). This perhaps explains the use of the expression in melius revocamus in relation to cancellation. If liberations were made in accordance with the will of their masters, their cancellation would hardly be determined as in melius. Similarly, it should be understood that the final statement of the constitution, under which the purpose of the provisions of this constitution was provided, was that no one on this occasion incipiat nolle quod voluit.

\subsection{Usurpation of Attalus}

As mentioned, the prefect of Rome, Priscus Attalus, had already received the purple from Alaric. He enjoyed it shortly. However having lost the dignity, he remained useful to the Visigoths. When the new leader of the Goths, Ataulf, despite marrying Honorius's sister, Galla Placidia, did not reach an agreement with the ruler of the West, once again he proclaimed Attalus the emperor in the year 415. But he did not earn any support. Constantius forced Ataulf to retreat behind the Pyrenees, and Attalus was captured, injured and sent to the Aeolian Islands. Ataulf was murdered soon after. After a short reign of Sigeric, Wallia became a new leader of the Visigoths. Constantius forced him to conclude an agreement: in exchange for the delivery of grain the Goths were obliged to release Galla Placidia and become allies of Rome.

\subsection{Constitution against legislative acts effected during the barbarian occupation (CTh. XV, 14,14).}

In these circumstances, after agreement with Visigoths, on behalf of both emperors a constitution relating to legal acts made during the reign of the barbarians ${ }^{103}$ was issued. That is the last constitution in title 14 of the fifteenth book of the Theodosian Code, explaining simultaneously its scope: previous constitutions concerned what had been done sub tyrannis, while the discussed constitution related in turn to what sub barbaris gesta sunt.

103 CTh. XV,14,14: Impp. Honorius et Theodosius aa. Constantio com(iti) et patricio. Sub clade barbaricae depopulationis, si qua aut per fugam aut per congregationem infelicium populorum indigne invidioseque commissa sunt, ad invidiam placatarum legum a callidis litigatorum obiectionibus non vocentur. Habeant omnium criminum impunitatem, qui evadendi forsitan non habuerunt facultatem, nisi eos eadem crimina iuvissent; non enim crimen dicitur, quod mortis adegit impulsus. Ex quo animadvertere cunctos litigatores congruum est, si quid depraedationis agnoverint, se recepturos, si tamen in eorum, quos pulsaverint, facultatibus abundare aut residere id potuerint comprobare. Dat kal. Mart. Rav(ennae), d. n. Theod(osio) a. VII. et Palladio v. c. conss. 
It is the abolition law. Acts done during clade barbaricae depopulationis, even if criminal, shall not be considered criminal offenses, if their performance were caused by fear for their lives caused by violence (terror) or a threat of death.

\section{Conclusions}

\subsection{Typology of the discussed constitutions}

Imperial constitutions collected in the title 14 of the fifteenth book of the Theodosian Code are linked with their content, determined already in the chapter title: abrogation of what was issued during the reign of tyrants and barbarians (De infirmandis his, quae sub tyrannis aut barbaris gesta sunt).

But it is a very general and capacious term. Most of these usurpations were relatively stable, while the war was often local in nature. So for a long time over large areas subjected to the power of usurpers life went on normally. Usurpers also benefited from all the privileges and prerogatives, which gave them the imperial dignity. Thus, cancellation of the effects of usurpations required many different activities, which, though subordinated to a single purpose, were directed against different forms of usurpers activity and therefore a variety of measures was applied.

For these reasons, several types of constitutions can be distinguished among constitutions collected in Title 14 of the fifteenth book. Moreover, they were already extracted when discussing their contents, but it is worth making clear and consistent classifications.

The most common type of constitution ordering a legal situation after the fall of usurpers relates to the usurper's legislation. The issuance of the constitution was one of the fundamental prerogatives of the emperor. In Rome, where the legal system was based on written law, the role of law as a tool for modeling social relations was significant. Therefore it was difficult for victorious emperors to disregard it. That group of constitutions include the acts of Constantine (CTh. XV, 14,1; XV, 14,3), Constantius (CTh. XV, 14,5) and, partly, Honorius and Theodosius II (CTh. XV, 14,13).

Another type of constitution dealt with the private law activities made during the usurpation. Only the Arcadius and Honorius constitution (CTh. XV, 14,10) concerns this issue. Other constitutions combine this theme with others: the constitution of Arcadius and Honorius (CTh. XV, 14,9) - with the cancellation of public acts (appointment of consuls), the constitution of Valentinian II, Theodosius and Arcadius (CTh. XV, 14,8) - with the annulment of dignities conferred by the usurper, but most often it is linked with the repeal of legislative acts. So did the constitutions of Constantius II (CTh. XV, 14,5) as well as Honorius and Theodosius II (CTh. XV, 14,13). 
With normative acts the problem of judgments was connected, especially due to the fact that imperial judgments in Roman law - decrees - had the character of the constitution. All those acts were issued in the emperor's name (on behalf of the emperor). It is often impossible to separate this question from the issue of private law acts. The constitutions of: Constantine (CTh. XV, 14,2) as well as Valentinian II, Theodosius and Arcadius (CTh. XV and XV 14,7, 14,8 - along with the private law activities) concerned judgements.

Usurpers lavished dignities willingly enough since they needed supporters. Resolving this issue was of significant importance for the legitimate emperors due to the double effect of these action. Firstly, the cancellation of granted dignities was a consequence of the recognition the usurper's reign as illegal. Secondly, and perhaps more importantly, the beneficiaries of these appointments were the supporters of the usurpation. This problem could not remain unresolved. The constitutions of Constantine (CTh. XV, 14,4), Valentinian II, Theodosius and Arcadius (CTh. XV and XV 14,6, 14,8) as well as Arcadius and Honorius (CTh. $\mathrm{XV}$ and XV 14,11,14,12) were dedicated to it.

The "abolition law" of Honorius and Theodosius II (CTh. XV, 14,14) was unique. It was issued in other circumstances and it did not concern the legal situation left by the usurpers, but the actual situation caused by the invasion of the barbarians.

\subsection{The solutions}

Analyzing the significance of these constitutions, in the first place it should be noted that they were always issued by all co-rulers of the Empire, though usurpations (ignoring the reign of Licinius, which, precisely speaking, was not an usurpation) usually concerned only the western part of the state. This practice - although going beyond issues of abrogating the effects of usurpation clearly shows the ideological unity of the Empire, even after the year 395, when according to the traditional history - it was finally divided into two independent state organisms. Although the rules of Eugenius and Heraclian and the Visigoths occupation concerned only the West (Italia, Gaul and Africa), their effects were jointly repaired by emperors reigning in Rome (and in practice in Milan or Ravenna) and Constantinople.

Different circumstances of both usurpations and the situation that occurred after their suppression, as well as the different policy and position of the emperors themselves resulted in different solutions contained in the constitutions. The gravest solution of the usurpers legislation issue was their overall repeal. This, however, happened quite rarely. It was done by the very powerful Constantine in the year 324, after the overthrow of Licinius (CTh. XV, 14,1), however, after defeat of Maxentius in 313 (see CTh.. XV, 14,3) this solution was not used. An 
equally definite tone was present in the constitution of Honorius and Theodosius II, after the defeat of Heraclian (CTh. XV, 14,13). Sometimes the constitutions restricted themselves to the repeal of what had been issued against the law (implicitly - not everything). Such a solution was applied by Constantius II (CTh. XV, 14,5). Similarly, Constantine the Great, after defeating Maxentius, shared his legislations on illegal acts (which were revoked) and acts consistent with the law, which were maintained in force (CTh. XV, 14,3).

Judicial rulings could likewise proceed. (These issues were already discussed above). In that case, formal requirements that were in conflict with requirements of legal relations and the principles of justice. Complete repeal of them was perhaps stipulated by constitutions of Valentinian II, Theodosius and Honorius after the fall Maximus (CTh. XV, 14,7, XV 14,8) and the constitution issued after the usurpation of Heraclian (CTh. XV, 14,13). In 325 Constantine, as in 313, divided judgments into legal and illegal ones (XV CTh., 14,2) and depending on that division revoked them or kept them in force. Probably a similar solution was adopted in the year 389 in the constitution of CTh. XV, 14,8 by three emperors.

It is obvious that the legitimate emperor could not tolerate dignities conferred by the usurper, especially since they strengthened the opponents of legal ruler. Therefore, all constitutions regarding this problem contained provisions ordering withdrawal of conferred dignities. They differ only in the way of treating their beneficiaries. The constitution of Valentinian II, Theodosius and Arcadius (CTh. XV, 14,6) only overrode promotions and restored the previous state. The CTh. XV, 14,8 constitution of the same emperors as well as constitution of Arcadius and Honorius (CTh. XV, 14,9) did not contain other provisions aside from those depriving beneficiaries of their dignities. The importance of another constitution (CTh. XV, 14, 11) is questioned, but it seems that it has the nature of an amnesty.

Activities of private law where usually left in force. So did Constantius II (CTh. XV, 14,5), Valentinian II, Theodosius and Arcadius (CTh. XV, 14,8), Arcadius and Honorius (CTh. XV, 14,9). However the next constitution of Arcadius and Honorius (CTh. XV, 14,10) determined the invalidation of consequences of legal acts, but it regarded only one type of acts carried out by the usurper, moreover, to the detriment of the imperial treasury. Except for cancellation of the effects of usurpation of Heraclian, liberations made at the time of usurpation were always left in force ${ }^{104}$.

104 W. W. Buckland, The Roman Law of Slavery: The Condition of the Slave in Private Law from Augustus to Justinian, Cambridge 2001 [reprint as of 1908], p. 454. 


\subsection{Supposed reasons for collection of the constitutions in the Theodosian Code}

One of the most important features of the Theodosian Code, that distinguishes it from the private codifications of the previous centuries, was its exclusivity. All constitutions which were not covered by it lost their legal force. Therefore, by not inserting usurpers' legislation in it, meant the abrogation of their legal force. There was no need to place derogating legislations in the Code. As it was already mentioned, Theodosian compilers did not act consequently, since they added the constitutions of Licinius, and - probably - of Maximus ${ }^{105}$ to the Code.

These constitutions are classic episodic laws. They concerned the specific situation and the particular time. Along with the lapse of time they were losing their legal significance. So if a tyrant's legislation was annulled, the legal consequences were revoked, judgments were repealed and re-released, and men who received dignities died long ago, their function was ended. They fulfilled their role and were no longer needed. So why did codifiers put these constitutions into the Code? The answer that comes to mind is to draw attention to their propaganda tone: the details of their provisions are irrelevant, but the general condemnation and outlawing of usurpation is important. It was expressed mostly in the provisions of constitutions against Maximus (CTh. XV, 14,8) and Heraclian (CTh. XV, 14,13), providing damnatio memoriae and removing all mentions about both the usurpation and the usurper.

It could not be excluded that some provisions of the usurper's legislation, or acts done during his times had some practical importance. It could manifest itself most simply in property law and inheritance law, which are branches of law of such a nature that demonstrates a long life and relationship with previous legislations.

Looking for reasons of collecting the discussed constitutions into the Theodosian Code and even creating a separate title devoted to them, it should be indicated the lack of clear rules regarding the transfer of power in the Late Empire (Diocletian's tetrarchy, the only exception, did not survive its inventor). This was conducive for many coups detat and palace revolutions, which was subsequently inherited by the Byzantine Empire. This lack of rules caused the situation that it was hard to find an indisputable designation for the - simple in theory - definition of a tyrant (the one who gained power against the law). Therefore, clear condemnation of the overthrown rulers constituted - instead of the rules of inheritance or election - legitimacy of recent (current) augustuses.

105 T. Honoré, op. cit., p. 187. 
The logic of all these constitutions remains the same: the lawful emperor refers to the usurpers' legal output. Whoever refers to the continuity with legitimate rulers (as did Theodosius II), is the legitimate ruler, and his potential or real-life opponents are tyrants. Thus, the memory of old times and the episodic recall of legislation is used for the purposes of current policy.

\section{Bibliography}

Agudo M. I. D., Estudio léxico de „iura y leges” en el derecho roman vulgar occidental, Madrid 2003.

Brown P., Power and Persuasion in Late Antiquity: Towards a Christian Empire, Madison 1992.

Buckland W. W., The Roman Law of Slavery: The Condition of the Slave in Private Law from Augustus to Justinian, Cambridge 2001 [reprint as of 1908].

Corcoran S., The Empire of the tertarchs. Imperial pronouncements and government $A D$ 284-324, Oxford 2000, Encyclopaedia of the Roman Empire, New York 1992.

Ecribano M. V., Constantino y la rescissio actorum del tirano-usurpador, „Gerión” 1998, no. 16.

Escribano M. V., La ilegitimidad política en los textos historiográficos y jurídicos tardíos (Historia Augusta, Orosius, Codex Theodosianus), "Revue Internationale des Droits de l'Antiquités” 1997, 3e Série, Tome XLIV.

Escribano M. V., Usurpación y religión en el s. IV d. de C. Paganismo, cristianismo y legitimación política, „Antigüedad y cristianismo: Monografías históricas sobre la Antigüedad tardía" 1990, no. 7.

Harries J., Law and Empire in Late Antiqiuty, Cambridge 1999.

Honoré T., Law in the crisis of Empire 379-455 AD: the Theodosian dynasty and its quaestors: with the Palingenesia of laws of the dynasty, Oxford 1998.

Ilski K., Maciejewski W., Technika redagowania Kodeksu Teodozjusza na tle ustawodawstwa antynestoriańskiego, „Czasopismo Prawno-Historyczne” 1996, nr 48 , z. 1-2.

Jaczynowska M., Pawlak M., Starożytny Rzym, Warszawa 2008.

Janiszewski P., Eunapius of Sardis and the Solar Eclipse during the Battle on River Frigidus, [in:] Euergesias Charin, Studies presented to Benedetto Bravo and Ewa Wipszycka by their Disciples, ed. T. Derda, J. Urbanik, M. Węcowski, Warsaw 2002. 
Janiszewski P., Żywioły w służbie propagandy, czyli po której stronie stoi Bóg. Studium klęsk i rzadkich fenomenów przyrodniczych u historyków kościoła IV $i$ V wieku, [w:] Chrześcijaństwo u schyłku starożytności: studia źródłoznawcze, red. T. Derda, E. Wipszycka, t. 3, Kraków 2000.

Kęciek K., Początek odrodzenia pogańskiego na Zachodzie i śmierć Walentyniana II, „Przegląd Historyczny” 1990, nr 81.

Kolańczyk K., Prawo rzymskie, Warszawa 1997.

Kotula T., Uzurpator Magnencjusz a ludność prowincji, [w:] Studia z dziejów antyku. Pamięci Profesora Andrzeja Kunisza, red. W. Kaczanowicz, Katowice 2004.

Litewski W., Historia źródeł prawa rzymskiego, Kraków 1989.

Litewski W., Studia nad rzymskim postępowaniem kognicyjnym, Kraków 1971.

Litewski W., Rzymski proces cywilny, Warszawa - Kraków 1988.

Mazzarino S., Il basso impero. Antico, tardoantico ed èra costantiniana, V. 1, Roma - Bari 1975.

Mazzarino S. , L'Impero romano, Roma-Bari 1973.

Mossakowski W., Azyl w późnym Cesarstwie Rzymskim, Poznań 2000.

Oxford Classical Dictionary, Oxford 1999.

Palanque J. R., L'empereur Maxime, [in:] Les Empereurs romains d'Espagne, Paris 1965.

Rozwadowski W., Prawo rzymskie. Zarys wykładu wraz z wyborem źródeł, Poznań 1991.

Sanz R., Aproximación al estudio de los ejércitos privados en Hispania durante la antiguedad tardia, „Gerión” 1986, no. 4.

Schlinkert D., Ordo senatorius und nobilitas: Die Konstitution des Senatsadels in der Spätantike, Stuttgart 1996.

Seeck O., Regesten der Kaiser und Päpste, Stuttgart 1929.

Sitek B., Infamia w ustawodawstwie cesarzy rzymskich, Olsztyn 2003.

Słownik cesarzy rzymskich, Poznań 2001.

Stachura M., Kodeks Teodozjusza - nowo odkrywane źródło historyczne, „Przegląd Historyczny" 2006, nr 3.

Storia di Roma, v. 3, p. 1. L'Età tardoantica: I crisi e transformazioni, Torino 1993.

Torres R. C., Magno Clemente Maximo, Santiago 1945.

Trout D. E., Paulinus of Nola, Berkeley - Los Angeles - London 1999.

Turpin W., Formula, processo and proceedings extra ordinem, „Revue Internationale des Droits de l'Antiquité", 3e Série, Tome XLVI 1999.

Więckowski S., Z dziejów ostatniej reakcji pogańskiej w Rzymie, „Przegląd Klasyczny” 1937, nr 3. 
Wipszycka E. (red.), Vademecum historyka starożytnej Grecji i Rzymu. Źródłoznawstwo starożytności klasycznej, t. I/II, Warszawa 2001.

Wołodkiewicz W., Ius et lex w rzymskiej tradycji prawnej, „Ius et Lex” 2002, nr 1.

Wołodkiewicz W., Promulgacja Kodeksu Teodozjusza na posiedzeniu senatu miasta Rzymu, „Palestra” 2006, nr 1-2.

Wołodkiewicz W., Zabłocka M., Prawo rzymskie. Instytucje, Warszawa 2009.

Zabłocka M., U źródeł współczesnego prawodawstwa, [w:] Z dziejów kultury prawnej. Studia ofiarowane Profesorowi Juliuszowi Bardachowi w dziewięćdziesięciolecie urodzin, Warszawa 2004.

Zabłocki J., Kompetencje 'patres familias' i zgromadzeń ludowych $w$ sprawach rodziny w świetle 'Noctes Atticae' Aulusa Gelliusa, Warszawa 1990.

Zimmermann R., The Law of Obligations. Roman foundations of the Civilian Tradition, Oxford 1996.

Ziółkowski A., Footnotes in Sokrates Scholastyk. Historia Kościoła, Warszawa 1986.

Ziółkowski A., Historia Rzymu, Poznań 2005. 